\title{
DEGREE OF WASTEWATER TREATMENT VERSUS TYPES OF REUSES: CASE STUDY, SAUDI ARABIA
}

\author{
O.S. ABURIZAIZA ${ }^{1}$ \\ G.A. MAHAR ${ }^{1,2^{*} \text {, }}$
}

\author{
${ }^{1}$ Unit for Ain Zubaida Rehabilitation and Groundwater Research \\ King Abdulaziz University, Jeddah, Saudi Arabia \\ ${ }^{2}$ Federal Urdu University of Artys Science and Technology
} Karachi, Pakistan
Received: 06/01/2016

Accepted: 04/05/2016

Available online: 22/06/2016 *to whom all correspondence should be addressed: e-mail: gamahar@kau.edu.sa

\section{ABSTRACT}

The Council of Ministers issued a Royal decree number M/6 $1421 \mathrm{H}$, corresponding to 2000 AD. The decree stated that, in Saudi Arabia, all wastewater should be treated at the tertiary level, without any discrimination (in terms of the type of reuse and discharge locations). The aim of this article is to discuss and elaborate the royal decree (2000AD), showing its limitations and recommending several modifications. This paper is a review and analysis of treated wastewater reuse in Kingdom of Saudi Arabia (KSA) and impact of implementation of royal decree for the treatment of wastewater reuse in future. Moreover, a critical appraisal of the use of tertiary treatment was done by elaborating negative impact of tertiary treatment and comparing a review of treatment of wastewater reuse in USA. It is emphasized in the paper that degrees of wastewater treatment should depend on: (a) types of reuses/discharges, methods of irrigation and local environmental conditions, and (b) whether irrigation takes place in restricted or unrestricted agriculture and types of crops. Thus, the Saudi Royal Decree (2000AD) that requires wastewater treatment up to a tertiary level needs to be re-evaluated and modified. The article suggested correlating the degree of wastewater treatment with the intended reuse, discharge locations and the degree of exposure to the public.

Keywords: Wastewater, Tertiary Treatment, Royal Decree, KSA, Water

\section{Introduction}

The world is confronted by an ever increasing shortage of water, especially in arid and semiarid regions such as Africa, South Asia, Southern Europe, and the Middle East (Gatica and Cytryn, 2013). Future population growth and water scarcity also pose significant risks to global food security (Hanjra and Qureshi, 2010). Population growth and water scarcity also drive the need to reuse wastewater for irrigation and other uses in many countries (Scheierling et al., 2010). The reuse of treated wastewater (RTWW) for irrigation is a practical solution for overcoming water scarcity, especially in arid and semiarid regions of the world (Gatica and Cytryn, 2013).

Although wastewater treatment is widely recognized as a major factor for water quality (US EPA, 2004), the UN Environment Program (UNEP) estimates that $90 \%$ of the developing world does not treat any of its wastewater before it is released directly back into the environment (UNEP, 2010). There are currently no globally comparable data on the percentage of wastewater treatment at the national scale to aid in the assessment of this effort (Sato et al., 2013; Baum et al., 2013). Wastewater irrigation can make a 
sterling contribution to reducing water demand, recycling nutrients, improving soil health and cutting back the amount of pollutants discharged into the waterways (Hanjra, 2012).

Wastewater is typically collected through sewerage system in municipal areas. Treatment of wastewater entails a step-wise process that occurs in primary, secondary, and tertiary stages (Metcalf, 1991). Primary treatment involves basic screening and filtration processes to remove settle-able and partially suspended solid and reduce its biochemical oxygen demand (BOD) to about 50\%. BOD is an indicator to monitor wastewater quality that assesses the amount of oxygen and microorganisms need to consume to break down the organic material present in wastewater (Florke, 2013; Rao et al., 2013). Secondary treatment uses biological processes to break down the dissolved organic matter and the remaining suspended solid after primary treatment. Secondary treatment can remove up to $90 \%$ of BOD and total suspended solids (Lawrence, 2010).

Wastewater contains microbes and chemicals that pose risk to human and environmental health (Hanjra, 2012). Untreated or partially treated wastewater creates health and environmental hazards, mainly pollution of fresh water resources, particularly riverbeds (Hophmayer-Tokich, 2008). Improved management of wastewater use can offer positive-sum solutions in human welfare and the environment. Health risk concerns and cost considerations are key obstacles to wastewater reuse. Reliable data of future wastewater supply and demand are needed for better planning and risk management (Duong and Saphores, 2015; Asano and Levine, 1996).

Wastewater governance refers to the guidelines, regulations, policies and laws that have been developed to guide wastewater use for agricultural and other uses, and to minimize the risk to public health and the environment (Hanjra, 2012). Scarcity of water in the Middle East is the problem of decades but introduction of desalination of water has somehow solved the problem. RTWW is also an encouraging issue especially in Saudi Arabia. Due to the dynamic spatio-climatic conditions with different geomorphic and geologic environment, groundwater level is not much higher to meet the increasing population (Mahar, et al., 2014). There are many alternates available as seawater desalination and wastewater treatment are major one. The KSA has many times done efforts for the reuse of treated wastewater and has developed several standards for the wastewater reuse for certain purpose. In Saudi Arabia, Council of Ministers issued a Royal decree \# M/6 $1421 \mathrm{H}$, corresponding to 2000 AD (Bureau of Experts at the Council of Ministers, 2000) for the treatment of wastewater and its reuses. In 2003, the Ministry of Municipal and Rural Affairs (MMRA) issued some standards for the reuse of wastewater in certain sectors of water use. In 2006, standard for wastewater reuse in agriculture were issued by Ministry of Water and Electricity (MWE) (Al-Jasser, 2010; MWE, 2006).

\section{Wastewater Treatment Policy in Kingdom of Saudi Arabia (KSA)}

Keeping in view the present and future conditions of scarcity of water in the Saudi Arabia, the Royal decree (\# M/6 $1421 \mathrm{H}$ ), issued in 2000 AD emphasized that any kind of wastewater generating in Saudi Arabia should be treated at the tertiary level, without any discrimination. The interpretation of the decree is that regardless of the category of reuse of wastewater, the discharge locations, and the degree of exposure to the public, the treatment should be at the tertiary level. The requirements of the Royal decree are very stringent. In practical applications, if the reuse is for irrigation, then, the degree of treatment should depend upon whether the crops are edible or non-edible. Further, if the crop is edible, then the degree of treatment should depend upon whether it is to be consumed raw or cooked. It also should depend upon whether the crop is a root crop, leafy vegetable or crops grown on trellises (EPA, 2012). If the treated wastewater is to be discharged, then the discharge location should depend upon the degree of treatment, whether it is a wadi (Basin) or a sea (Missimer, 2014). If it is a wadi (Basin), it depends upon whether or not it is a drinking water supply. The degree of treatment also depends upon the degree of exposure to the public (e.g., if it is a median where exposure to the public is very limited, or if it is inside the city (parks, golf courses), where the exposure frequency and level is high). Since a considerable number of the existing 
wastewater treatment plants in Saudi Arabia are for the secondary treatment, those have to be upgraded to the tertiary treatment level to comply with the decree.

Upgrading of the existing secondary wastewater treatment plant is only justified if the need is rational. However, as will be explained later in this paper, the majority of wastewater treatment plants do not need upgrading because of potential reuse/disposal of treated wastewater. Therefore, this article thoroughly discusses and elaborates on the royal decree $(2000 \mathrm{AD} / 1421 \mathrm{H})$, showing its limitations and recommending appropriate modifications.

This article is an attempt to discuss and analysis the RTWW in Saudi Arab and need of different level of treatment of wastewater to be used in different sectors, keeping focus on the royal decree $(2000 A D / 142 H)$. The required degree of treatment for different treated wastewater reuses and discharges in USA was also come under discussion as reference to get the comparison and guideline, as some states of USA have similar climatic conditions as Saudi Arabia.

\section{Collection and Analysis of Relevant Data}

Desalinated by seawater through reverse osmosis is one of the most reliable water supply solution is in KSA. Other sources are desalinated brackish groundwater, seasonal water reserves by Dams and treated wastewater (Missimer, 2014). Available data of municipal water supply from desalinated water and groundwater reserve, public sewerage, treated reused wastewater with its quantity \& types of reuses and discharged quantity were collected from MOWE as shown in the table $1 \& 2$.

Table 1. Amount of water distributed by the Main sources (2007-2013) in Million Cubic Meters

\begin{tabular}{cccccccc}
\hline Year & $\mathbf{2 0 0 7}$ & $\mathbf{2 0 0 8}$ & $\mathbf{2 0 0 9}$ & $\mathbf{2 0 1 0}$ & $\mathbf{2 0 1 1}$ & $\mathbf{2 0 1 2}$ & $\mathbf{2 0 1 3}$ \\
\hline Desalination & 1,067 & 1,063 & 1,145 & 1,258 & 1,476 & 1,546 & 1,594 \\
\% of total water use & 54 & 53 & 54 & 55 & 61 & 61 & 58 \\
\hline GW \& Dams reservoirs* & 910 & 942 & 978 & 1,025 & 947 & 981 & 1,137 \\
\% of total water use & 46 & 47 & 46 & 45 & 39 & 39 & 42 \\
\hline Total & 1,977 & 2,005 & 2,123 & 2,283 & 2,423 & 2,527 & 2,731 \\
\hline
\end{tabular}

Source: Annual Report, MOWE (2013), Riyadh, Saudi Arabia.

*The author could not obtain separate figures regarding groundwater and use of water behind the dams.

Municipal water supply in 2013 was 2,731 MCM (Table 1). If the average municipal wastewater generation is assumed to be around $75 \%$ of water consumption (Hammer, 1996), then the total generated wastewater can be estimated to be about 2,048 MCM in 2013. The treated wastewater in 2013 was 1518 MCM. This indicates that $529 \mathrm{MCM}$ of wastewater remained untreated. The used treated wastewater is 383 MCM in 2013 (Table 2).

The data from 2007 to 2013 in table 1 shows that water uses from both sources of groundwater and desalinated water has increased with time. It is calculated from the table 1 that the annual average growth rate of the total water uses is $2.6 \%$. If it continues with the same growth rate, the estimated water demand in 2030 will be 6,896 million cubic meters (MCM). Consequently, the generated wastewater will increase to $5,172 \mathrm{MCM}$ that is about $75 \%$ of total water used. Rest of the water will be (1724 MCM) consumed. Thus, more tertiary wastewater treatment plants are to be built. If the Royal decree (2000AD/1421H) remains in force, this upgrading of primary and secondary treatment plants and building new tertiary treatment plants will require extra costs.

Table 2 shows degree and quantity of treated wastewater and its reuses in different sectors in KSA. Seven major provinces of KSA (Riyadh, Makkah, Eastern Province, Aseer, Qaseem \& Jazan) treated about 98 $\mathrm{MCMD}^{-1}$ from tertiary treatment plants. Some provinces use both secondary and tertiary plants for generating treated wastewater. About $4.16 \mathrm{MCMD}^{-1}$ on average of wastewater is treated but only $26 \%$ of it is reused and the rest of the water is discharged into the wadi or sea (Figure 1). About $41 \%$ of treated water is discharge to wadis and $33 \%$ is discharge into the sea. 
About $3 / 4$ of the amount of wastewater is not properly used. Riyadh, Makkah and Eastern provinces are the major producer of treated wastewater from water treatment plants (Figure 2). These provinces are producing more than 1 million cubic meters per day of treated wastewater while rest of the provinces has capacity to produce about 0.2 million cubic meters/day or lesser. According to the data provided in 2013, Riyadh is still using $16 \%$ of its total production while Makkah uses $14 \%$ and eastern province used about $35 \%$ of treated wastewater production. This shows the brutally exploitation of resources. Madina produces about $2.2 \mathrm{MCMD}^{-1}$ and uses $85 \%$ of its production that is somehow lesser wastage. Brutally exploitation of resources in terms of wastage of wastewater can be vividly seen from figure 3 . This figure shows how the treated wastewater is exploited. In some small provinces whole treated water is discharged into the wadis. This figure shows that abundant of treated wastewater is mismanaged in KSA. As the treated wastewater is not used for drinking purposes, therefore, this water is used for recharging groundwater. After the natural filtration processes, this water could be used for multi purposes.

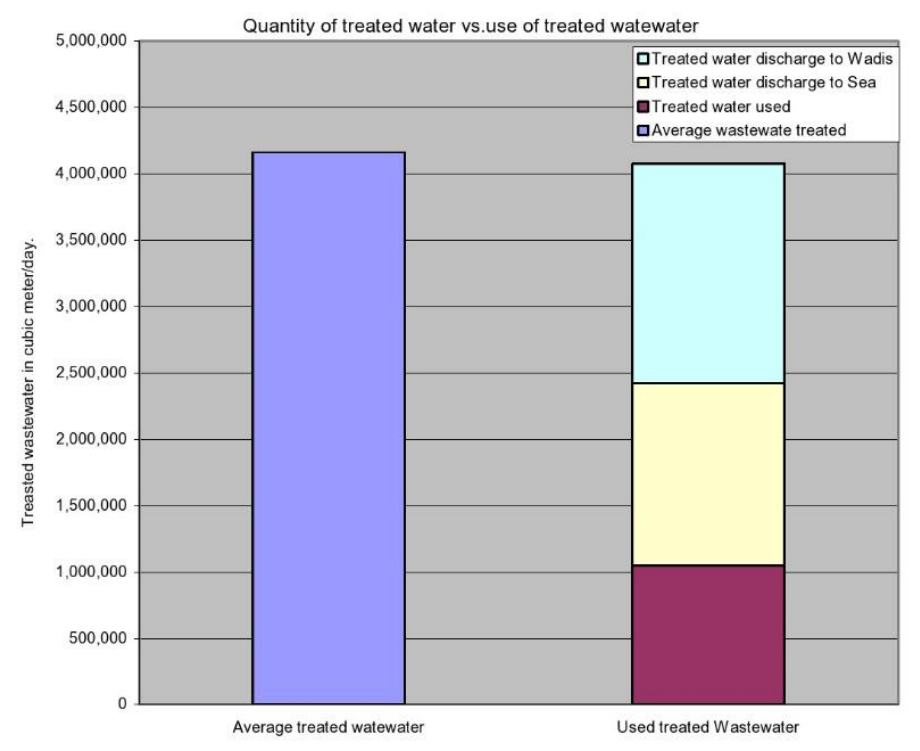

Figure 1. Figure shows total quantity of water treated in KSA and it uses in different sectors

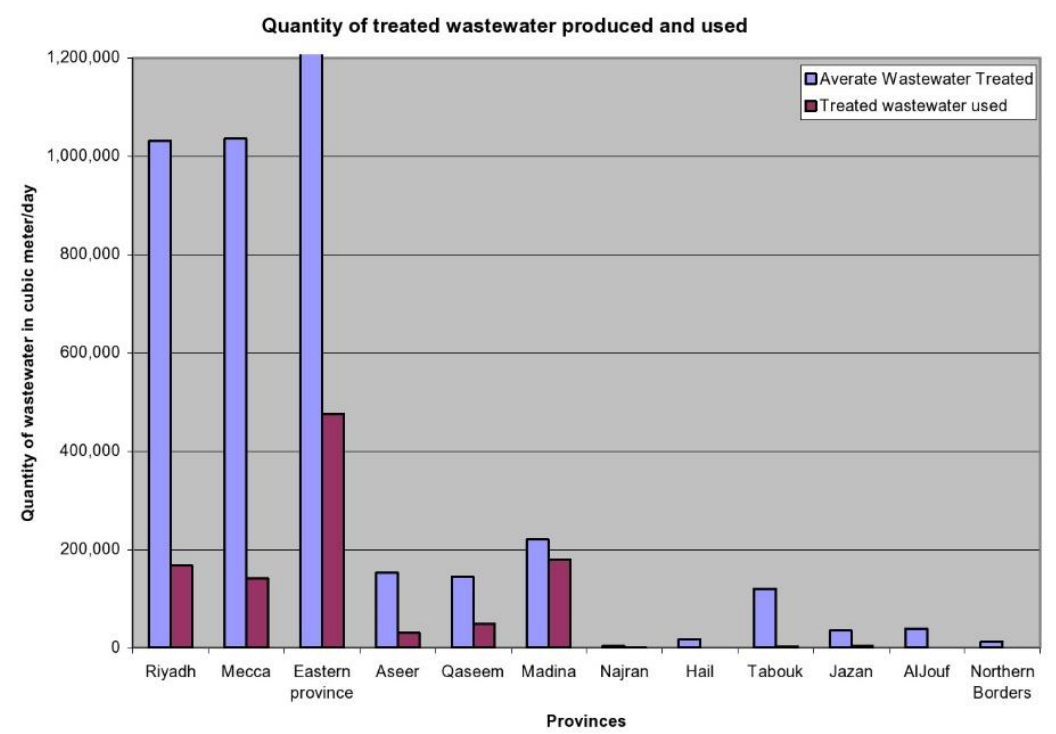

Figure 2. This figure shows the quantity of treated wastewater and its uses in all provinces of KSA 


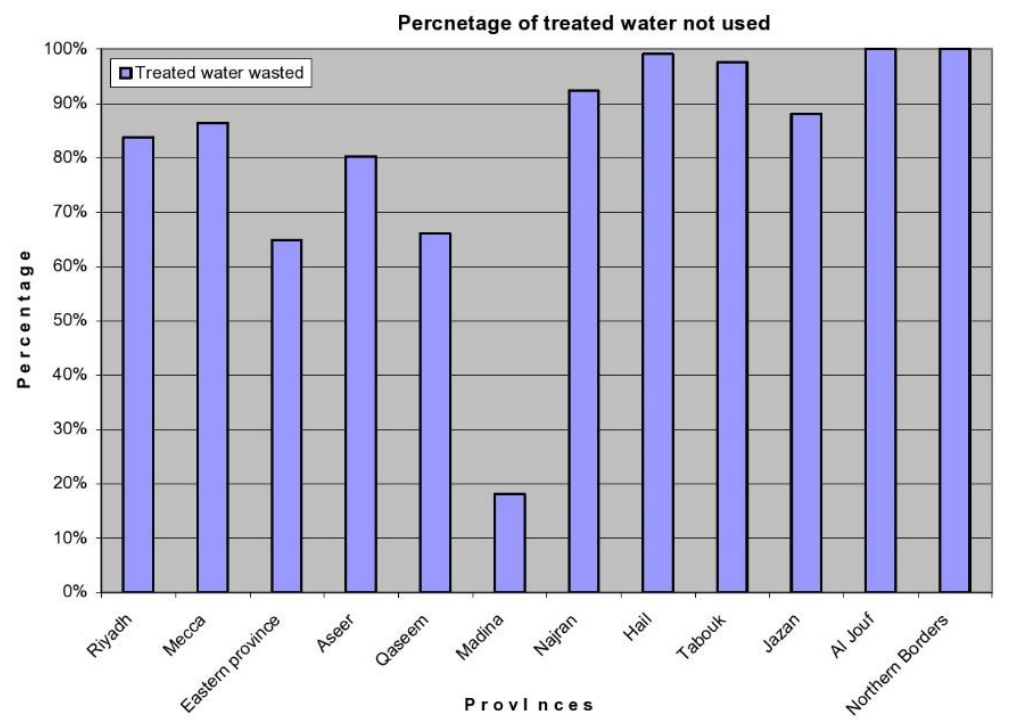

Figure 3. Figure shows percentage of treated wastewater that is wasted in the wadis or poured into the sea

The percentage of reused treated wastewater to the total wastewater was $18.7 \%$ which is considered very low. This also means that a considerable quantity of sewerage infrastructures (sewers and wastewater treatment plants) is still needed and should be built all over KSA. Table 2 shows that 33 primary and secondary treatment plants should be upgraded to the tertiary level if the Royal decree $(2000 \mathrm{AD} / 1421 \mathrm{H})$ is to be practiced. This is in addition to many small cities and towns which do not have sewerage network yet.

Table 2 shows that out of $4.162 \mathrm{MCMD}^{-1}$ treated wastewater, only $1.050 \mathrm{MCMD}^{-1}$ is used for different reuses. Further, $1.372 \mathrm{MCMD}^{-1}$ is discharged into seas and $1.657 \mathrm{MCMD}^{-1}$ is discharged into wadis. This water may be useful for recharge of wadis groundwater and naturalize seawater. The water discharged into seas through outfalls does not need tertiary treatment; secondary treatment will be adequate. However, for discharges into wadis, it should discriminate between non-drinking and drinking water supplies. For the first one (non-drinking), secondary treatment will be adequate, while, for the second one (drinking), wastewater should be treated at the tertiary level or even higher. This shows the necessity of studying the wadis as sources of water, for the time being and for the future, to decide on the required degree of wastewater treatment. Table 1 also shows that the RTWW are a mixture of restricted, unrestricted agricultural/recreational irrigation (landscaping, road bathing and so on). Not all these reuses require tertiary treatment.

It is highly recommended that treated wastewater (secondary/tertiary) should not be discharged, into seas at all. This should be completely used (their utilization should be exhausted) because discharge into seas is a sort of waste of precious water. Usually, discharging the treated wastewater into wadis is not for recharging purposes but for getting rid of redundant treated wastewater. This sometimes leads to misuse, for example, discharging tertiary-treated wastewater into a non-drinkable water supply source (wadi) and at the same time discharging secondary-treated wastewater into a drinkable water supply source (wadi). Therefore, studying and identifying the types of wadi as sources of drinkable and non-drinkable water should be carried out and discharges should be planned accordingly.

\section{Necessity of tertiary treatment for reuses}

A was carried out to evaluate the wastewater treatment plants in KSA and to improve their performance. The study recommended several degrees of treatment processes according to the intended reuse and discharge location study (aburizaiza, 1994). 
Table 2. Main public sewer and wastewater treatment plants, degree of treatment, amount of treated wastewater, amount used and types of reuses/disposal in KSA.

\begin{tabular}{|c|c|c|c|c|c|c|c|c|c|c|}
\hline \multirow[b]{2}{*}{ Region } & \multirow{2}{*}{$\begin{array}{c}\begin{array}{c}\text { Sewer } \\
\text { system }\end{array} \\
\text { Piped } \\
\text { length } \\
\text { (km) }\end{array}$} & \multirow{2}{*}{$\begin{array}{l}\text { Number } \\
\text { of } \\
\text { plants }\end{array}$} & \multicolumn{3}{|c|}{$\begin{array}{l}\text { Treatment plants: degree and } \\
\text { capacity in } \mathrm{m}^{3} / \text { day } \\
\end{array}$} & \multirow{2}{*}{$\begin{array}{l}\text { Avg. treated } \\
\text { wastewater } \\
\qquad \mathrm{m}^{3} \mathrm{~d}^{-1}\end{array}$} & \multirow{2}{*}{$\begin{array}{l}\text { Used } \\
\text { treated } \\
\text { wastewater } \\
\mathrm{m}^{3} \mathrm{~d}^{-1}\end{array}$} & \multirow[b]{2}{*}{ Type of reuses of treated wastewater } & \multicolumn{2}{|c|}{$\begin{array}{l}\text { Discharged treated } \\
\text { wastewater to: }\end{array}$} \\
\hline & & & primary & Secondary & Tertiary & & & & Seas & Wadis \\
\hline Riyadh & 9,441 & 16 & 0 & 0 & 16923,300 & $1,031,247$ & 167,103 & $\begin{array}{c}\text { Restricted and unrestricted } \\
\text { irrigation,industrial purposes, flushing } \\
\text { sewers and Power plant cooling and } \\
\text { landscape irrigation }\end{array}$ & 0 & 864,144 \\
\hline Mecca & 6,002 & 14 & 0 & 9421,000 & $51,147,000$ & $1,035,194$ & 141,000 & $\begin{array}{c}\text { Unrestricted recreational and } \\
\text { agricultural irrigation and industrial } \\
\text { uses }\end{array}$ & 557,194 & 337,000 \\
\hline $\begin{array}{l}\text { Eastern } \\
\text { province }\end{array}$ & 5,416 & 21 & 326,900 & 11882,200 & 7914,750 & $1,354,073$ & 475,624 & $\begin{array}{l}\text { Unrestricted agricultural and } \\
\text { recreational irrigation }\end{array}$ & 795,844 & 0 \\
\hline Aseer & 3,140 & 11 & 0 & 0 & 11187,050 & 152,440 & 30,050 & $\begin{array}{l}\text { Restricted irrigation and in factories } \\
\text { and in landscaping and streets paving }\end{array}$ & 0 & 122,390 \\
\hline Qaseem & 2,539 & 5 & 0 & 214,000 & 3225,000 & 144,000 & 48,860 & $\begin{array}{l}\text { Unrestricted agricultural and } \\
\text { recreational irrigation and within the } \\
\text { plant }\end{array}$ & 0 & 95,140 \\
\hline Madina & 2,406 & 7 & 0 & 0 & 7334,000 & 220,000 & 180,000 & $\begin{array}{l}\text { Unrestricted recreational irrigation, } \\
\text { disposal to Wadi Al-Aqeeq }\end{array}$ & 0 & 40,000 \\
\hline Najran & 890 & 1 & 0 & 160,000 & 0 & 3,250 & 250 & Used within the plant & 0 & 3,000 \\
\hline Hail & 880 & 1 & 0 & 112,000 & 0 & 17,000 & 150 & Used within the plant & 0 & 16,850 \\
\hline Tabouk & 758 & 1 & 0 & 160,000 & 0 & 120,000 & 3,000 & Used within the plant & 0 & 117,000 \\
\hline Jazan & 489 & 8 & 0 & 0 & 835,200 & 35,200 & 4,200 & recreational irrigation & 19,000 & 12,000 \\
\hline AlJouf & 445 & 2 & 0 & 240,000 & 0 & 38,000 & 0 & Not used & 0 & 38,000 \\
\hline $\begin{array}{l}\text { Northern } \\
\text { Borders }\end{array}$ & 220 & 2 & 0 & 224,000 & 0 & 11,500 & 0 & Not used & 0 & 11,500 \\
\hline Total & 32,626 & 89 & 326,900 & $13,413,209$ & $98,566,300$ & $4,161,904$ & $1,050,237$ & Not Applicable & $1,372,038$ & $1,657,024$ \\
\hline
\end{tabular}

${ }^{1}$ Annual Report of Ministry of Water and Electricity (MOWE), Riyadh, Saudi Arabia (2013)

Official Report, General Directorate of Water in Medina Region, Head Office, number 44279/40036, date 2/13/2015.

Official Report, General Directorate of Water in Eastern Province, Head Office, number 91/30063/1436, date 2/5/2015.

Official Report, National Water Company in Jeddah, number 31339/36, date 3/29/2015.

Official Report, General Directorate of Water in Qaseem Region, Head Office, number 66/50133/1436, date 2/6/2015.

Official Report, General Directorate of Water in Aseer Region, Head Office, number 442/72029/1436, date 4/8/2015.

Official Report, General Directorate of Water in Jazan Region, date: 1/6/2015 
Table 3 explains relating the degree of treated wastewater and its reuse applications. Table (3) may need some modifications due to the environmental differences among the regions in KSA (such as the climatic factors, the types of soil and crops, and methods of irrigation). It can be noticed from Table (3) that different degrees of wastewater treatment are needed, depending upon the types of reuse/discharge locations. Thus, tertiary treatment of wastewater is not necessary in all reuses and discharges.

Table (3) points out that the biological treatment with partial disinfection and pre-treatment of industrial wastewater is acceptable for discharge into the sea, or (a) restricted irrigation of fodder, fiber, and seed crops, and (b) restricted landscape irrigation such as green areas with limited public access along streets and highways.

Table 3. Relationships between degrees of wastewater treatment and effluent disposal/reuses

\begin{tabular}{|c|c|c|}
\hline Degree of Treatment & $\begin{array}{c}\text { Description of Wastewater Treatment } \\
\text { Processes }\end{array}$ & $\begin{array}{l}\text { Method of Disposal or Reuse } \\
\text { Application }\end{array}$ \\
\hline $\begin{array}{l}\text { Biological treatment } \\
\text { with partial } \\
\text { disinfection }\end{array}$ & $\begin{array}{l}\text { Conventional biological treatment and } \\
\text { effluent disinfection } \\
\text { or } \\
\text { Multiple-cell stabilization ponds with } \\
\text { total detention time of at least } 30 \text { days }\end{array}$ & $\begin{array}{c}\text { Disposal to sea } \\
\text { or } \\
\text { restricted agricultural irrigation } \\
\text { of fodder, fiber and seed crops } \\
\text { non-potable groundwater }\end{array}$ \\
\hline $\begin{array}{l}\text { Biological treatment } \\
\text { with disinfection }\end{array}$ & $\begin{array}{l}\text { Extended biological treatment with } \\
\text { enhanced disinfection }\end{array}$ & Restricted landscape irrigation \\
\hline $\begin{array}{l}\text { Tertiary treatment for } \\
\text { pathogen removal }\end{array}$ & $\begin{array}{c}\text { Biological treatment, chemical } \\
\text { coagulation, granular-media filtration, } \\
\text { and disinfection } \\
\text { or } \\
\text { Aerated lagoons, multiple cell maturation } \\
\text { and ponds with a total detention time of } \\
\text { at least } 20 \text { days and disinfection }\end{array}$ & $\begin{array}{l}\text { Unrestricted agricultural or } \\
\text { landscape Irrigation } \\
\text { non-potable groundwater }\end{array}$ \\
\hline $\begin{array}{l}\text { Water reclamation for } \\
\text { pathogen and toxin } \\
\text { removals }\end{array}$ & $\begin{array}{l}\text { Biological treatment with denitrification, } \\
\text { chemical precipitation or lime } \\
\text { precipitation and neutralization, granular- } \\
\text { media filtration, and disinfection }\end{array}$ & $\begin{array}{l}\text { Uncontrolled discharge to wadi } \\
\text { with potable groundwater }\end{array}$ \\
\hline
\end{tabular}

${ }^{*}$ All these schemes assume pre-treatment of industrial wastewaters to remove toxins prior to discharge to the treatment plant. Source: Aburizaiza, O. S. et al. (1994)

The degree of treatment required for irrigation depends on whether the agricultural irrigation is restricted or unrestricted (FAO, 1992). If the treated wastewater is for discharge into a wadi, the degree of treatment will depend on whether the groundwater of the wadi is a drinking water supply source or not. If the irrigation is restricted to fodder, fiber, and seed crops at a controlled site and the groundwater is nonpotable, only biological treatment with partial disinfection is adequate (Iyad A. Husain, 2010; Aburizaiza, 1994). If the irrigation is unrestricted, namely private farm lands, the wastewater requires tertiary treatment for pathogen removal (Richard Helmer \& Evanildo Hespanhol, 1997).

However, in uncontrolled discharge into a wadi with potable groundwater source, water reclamation for pathogen and toxin removals is needed. The required processes in such cases are shown at the bottom of Table (3).

\section{Comparative Overview of Treated Wastewater Reuse/Discharge in the USA}

The Environmental Protection Agency, USA (EPA) suggests different required degree of treatment for each use/discharge, as shown in Table 4 (USEPA region 9, 2015). US EPA classified the treatment into primary, secondary, tertiary and advanced levels, and specified the uses and the required degrees of treatment. 
Table 4. Type of treatment processes and suggested uses at each level of treatment ${ }^{1,2}$

\begin{tabular}{|c|c|c|c|}
\hline \multicolumn{4}{|c|}{ Increasing Levels of Treatment; Increasing Acceptable Levels of Human Exposure } \\
\hline $\begin{array}{l}\text { Primary } \\
\text { Treatment: } \\
\text { Sedimentation }\end{array}$ & $\begin{array}{l}\text { Secondary Treatment: } \\
\text { Biological Oxidation, } \\
\text { Disinfection }\end{array}$ & $\begin{array}{l}\text { Tertiary treatment: } \\
\text { Chemical Coagulation, } \\
\text { Filtration, Disinfection }\end{array}$ & $\begin{array}{l}\text { Advanced, } \\
\text { renovation/treatment }\end{array}$ \\
\hline $\begin{array}{l}\text { No uses } \\
\text { recommended } \\
\text { at this level }\end{array}$ & $\begin{array}{l}\text { - Surface irrigation of } \\
\text { orchards and vineyards } \\
\text { - } \quad \text { Non-food crop irrigation } \\
\text { - } \text { Restricted landscape } \\
\text { impoundments } \\
\text { - Groundwater recharge of } \\
\text { non-potable aquifer* } \\
\text { - Wetlands, wildlife habitat, } \\
\text { stream augmentation* } \\
\text { - Industrial cooling } \\
\text { processes* }\end{array}$ & $\begin{array}{l}\text { - } \quad \text { Landscape and } \\
\text { golf course } \\
\text { irrigation } \\
\text { - } \text { Toilet flushing } \\
\text { - } \quad \text { Vehicle } \\
\text { washing } \\
\text { - Food crop } \\
\text { irrigation } \\
\text { - Unrestricted } \\
\text { recreational } \\
\text { impoundment }\end{array}$ & $\begin{array}{l}\text { Indirect potable reuse: } \\
\text { groundwater recharge } \\
\text { of potable aquifer and } \\
\text { surface water reservoir } \\
\text { augmentation* }\end{array}$ \\
\hline
\end{tabular}

${ }^{1}$ Suggested uses are based on Guidelines for Water Reuse, developed by U.S. Environmental Protection Agency (US EPA).

${ }^{2}$ While there are some exceptions, waste water in the United States is generally required to be treated to the secondary level. Some uses are recommended at this level, but many common uses of recycled water such as landscape irrigation generally require further treatment

* Recommended level of treatment is site-specific.

Source: EPA Water Division Region IX - EPA 909-F-98-001 WATER RECYCLING AND REUSE: THE ENVIRONMENTAL BENEFITS.

The US EPA stated that, secondary treatment (Biological Oxidation, Disinfection) is adequate for several uses (Table 4). It also stated that tertiary treatment is needed for certain uses, such as landscape, golf course irrigation and unrestricted recreational impoundments (US EPA, 2015). Further, it is stated that, in groundwater recharge of potable aquifers and surface water reservoir augmentation, advanced treatment is required. A good example is Orange County Project and Lake Tahoe (a recreational resort area) (Mike Wehner, 2010). The unit process after tertiary treatment is shown in Table (4). The US EPA does not recommend any uses if only primary sedimentation is to be practiced.

The authors suggests that primary treatment with adequate disinfection and efficient management may be practiced in limited uses such as irrigating the median of the highways outside cities and after midnight where public exposure is very limited. It can be noted from Table (4) that tertiary treatment is not required for every type of reuse, and also it may not be enough for certain other reuses. Therefore, the degree of treatment is a function of the type of intended reuse.

Wastewater reuse criteria adopted by Arizona, California and Nevada is shown in Table 5, (Felcia Marcus, 1998). It discriminates among (a) unrestricted and restricted urban reuses, (b) food and non-food crops, and (c) recreational reuses. It can be seen in Table (5) that the secondary treatment with disinfection is adequate for restricted urban and recreational reuses, and non-food crop irrigation. For unrestricted reuses, Arizona utilized an additional filtration operation to the secondary treatment and disinfection processes. California went further and included a coagulation process prior to filtration. Nevada, however, required secondary treatment and disinfection only. So it does not discriminate between restricted and unrestricted reuses. The author believes that excellent management and pre-caution should have been assumed in unrestricted reuse in Nevada. Without that (excellent management and pre-caution), only secondary treatment and disinfection may not be adequate. Nevada is an arid land like SA, so secondary treatment and disinfection with efficient management and pre-caution may be adequate in certain unrestricted reuses since it is not a populous state (exposure to the public is limited). Considering the 
criteria adopted in these states, it can be inferred that tertiary treatment is not needed in all wastewater reuses. Degree of treatment depends on the type of reuse and human exposure. Higher the degree of exposure to the public, the higher the degree of treatment required.

Table 5. Wastewater reuse treatment level criteria of Arizona, California and Nevada

\begin{tabular}{cccc}
\hline Use category & Arizona & California & Nevada \\
\hline $\begin{array}{c}\text { unrestricted urban reuse; } \\
\text { agricultural reuse: food crops; } \\
\text { unrestricted recreational reuse }\end{array}$ & $\begin{array}{c}\text { secondary treatment, } \\
\text { filtration, and } \\
\text { disinfection }\end{array}$ & $\begin{array}{c}\text { oxidized, } \\
\text { coagulated, filtered, } \\
\text { and disinfected }\end{array}$ & $\begin{array}{c}\text { secondary } \\
\text { treatment and } \\
\text { disinfection }\end{array}$ \\
\hline $\begin{array}{c}\text { restricted urban reuse; nonfood } \\
\text { crop irrigation; restricted } \\
\text { recreational reuse }\end{array}$ & $\begin{array}{c}\text { secondary treatment, } \\
\text { and disinfection }\end{array}$ & $\begin{array}{c}\text { secondary, oxidized, } \\
\text { and disinfected }\end{array}$ & $\begin{array}{c}\text { Secondary } \\
\text { treatment, and } \\
\text { disinfection }\end{array}$ \\
\hline
\end{tabular}

Source: Wu, L., et al. (2009)

The required degrees of treatment, for different types of reuses, in nine states of the USA are given in Table 6 (US EPA, 2012). It classifies the reuses into several classes/categories (see supplementary material). The Table shows that there are four degrees of treatment, depending upon the intended reuses. For example, in Arizona, for class A, secondary treatment, filtration and disinfection are required for unrestricted urban reuses. However, for class $B$, secondary treatment and disinfection are required for restricted urban reuse. For class $A$, secondary treatment, filtration and disinfection are required for agricultural reuse (food crops). However, for restricted urban reuse (class B), secondary treatment and disinfection are enough. The same argument goes for agricultural reuse of non-food crops. Arizona discriminates between restricted and unrestricted impoundments. Other states have recommended the required degree of treatment for all the above-mentioned reuses (Table 6). The conclusion is that the nine states of the USA recommend seven degrees of treatment, depending on the intended reuses/discharge locations.

Therefore, the requirement of only tertiary treatment of wastewater for all reuses prescribed in the Royal Decree $(2000 \mathrm{AD} / 1421 \mathrm{H})$ should be reconsidered and modified.

Table (6) shows agricultural reuse needs tertiary treatment for food crops in all the states. However, for nonfood and non-processed crops, in most of the states, secondary treatment with disinfection is enough. For restricted impoundments, in general, only secondary treatment is required. However, for unrestricted impoundments, California, Virginia and Washington require tertiary treatment, while Arizona requires only secondary treatment and disinfection.

For environmental reuse, Nevada requires only secondary treatment with disinfection, while North Carolina and Washington require tertiary treatment, and Florida requires secondary treatment, nitrification and basic disinfection.

For industrial reuse, Nevada and Virginia require secondary treatment with disinfection, while Washington and California require tertiary treatment.

Table (6) distinguishes between unrestricted and restricted urban reuses of treated wastewater across several states except North Carolina (which recommends type 1, filtration or the equivalent for both unrestricted and restricted).

\section{Negative Aspect of Tertiary Treatment}

There are two drawbacks in adopting tertiary and advanced treatment in developing countries such as SA. The first is the short supply of the skilled technicians (working in the sector) required for advanced treatment. This reduces the efficiency of the performance of the tertiary and advanced wastewater treatment plants. The second drawback is the high cost of the tertiary and advanced treatments, involved not only in the construction but also in operations and maintenance $(O \& M)$ of the plants. The high cost of $O \& M$ makes it difficult to continue with tertiary and advanced treatments. 
If the degree of treatment takes into consideration reuse/discharge location as factors, a considerable amount of cost can be saved which may be directly used to build sewerage systems in the areas lacking it. This will be better than building tertiary treatment plants in the areas served by secondary wastewater treatment plants, where tertiary treatments are not needed. Such an action will help control pollution much better.

Finally, what authors would like to conclude is that the degrees of wastewater treatment should depend on: (a) types of reuses, types of crops, methods of irrigation, and local environmental conditions, (b) whether irrigation takes place in restricted or unrestricted agriculture, and (c) the exposure to the public. Thus, the Saudi Royal Decree $(2000 \mathrm{AD} / 1421 \mathrm{H})$ that all wastewater should be treated to a tertiary level needs to be evaluated and modified again.

\section{Conclusion}

Royal Decree $(2000 \mathrm{AD} / 1421 \mathrm{H})$ declared that wastewater in SA should be treated the tertiary level regardless of the type of reuse/discharge location. In fact, the selection of the required level of treatment is based on the type of reuse, discharge location and the exposure of the treated wastewater to the public. Secondary treatment is required for non-edible crops. On the other hand, tertiary treatment is required for irrigating edible crops. It may not be enough if the intended reuse is for recharging a potable water supply to aquifer. The degrees of treatment and corresponding reuses are shown in the examples of US EPA and several states of the USA. Thus, authors recommend reconsideration of the Royal Decree. The Royal Decree should assign the required degree of treatment for each type of reuse/discharge. Finally, authors propose several degrees of treatment for several wastewater reuses/discharges.

\section{Recommendations}

Water resource planning and management should be performed for a long time horizon, taking into account the long-run accumulative effects and addressing potential future changes and uncertainties (Katsiardi, P., 2005). The recommendations are divided into primary and secondary.

\subsection{Primary}

1. Treated wastewater reuses and discharge locations in all regions of KSA should be identified according to the local need and the environmental, economic and social conditions.

2. then, for each reuse and discharge location, the suitable degree of wastewater treatment should be identified. This will enable KSA to control pollution and, at the same time, and to economize. RTWW more efficiently

3. In some cases, where there is more than one reuse of treated wastewater and/or discharge locations, authors suggest Figure 4 to be followed, which consists of five degrees of wastewater treatment: pretreatment of wastewater from cesspits, primary, secondary, tertiary and advanced treatments.

The authors suggest adopting stage I (shown in Figure 4) in every city and town to control pollution and meet the requirement of most of the reuses/discharges. If there is a reuse/discharge which requires tertiary treatment, then the second stage should be adopted. Through the same argument, if there is a reuse/discharge that requires an advanced treatment, then stage III (following the tertiary treatment) should be adopted. The capacity of the first stage should take all the expected volume of the wastewater, while the capacity of the second and the third stages should be equal to the expected quantity of the intended reuses/discharges.

4. Construction of tertiary wastewater treatment plants should not continue unless there is a need for it because of the high cost involved. The decree $(2000 \mathrm{AD} / 1421 \mathrm{H})$ should be re-evaluated and the degree of treatment should be highly correlated with the intended reuse/discharge of wastewater. 
5. Degree of treatment, intended reuses/discharge locations would have to be periodically updated. There should be a mechanism for monitoring treatment activities.

6. Local experts in environmental science, social science, economics and public health should be consulted in identifying reuses/discharge locations.

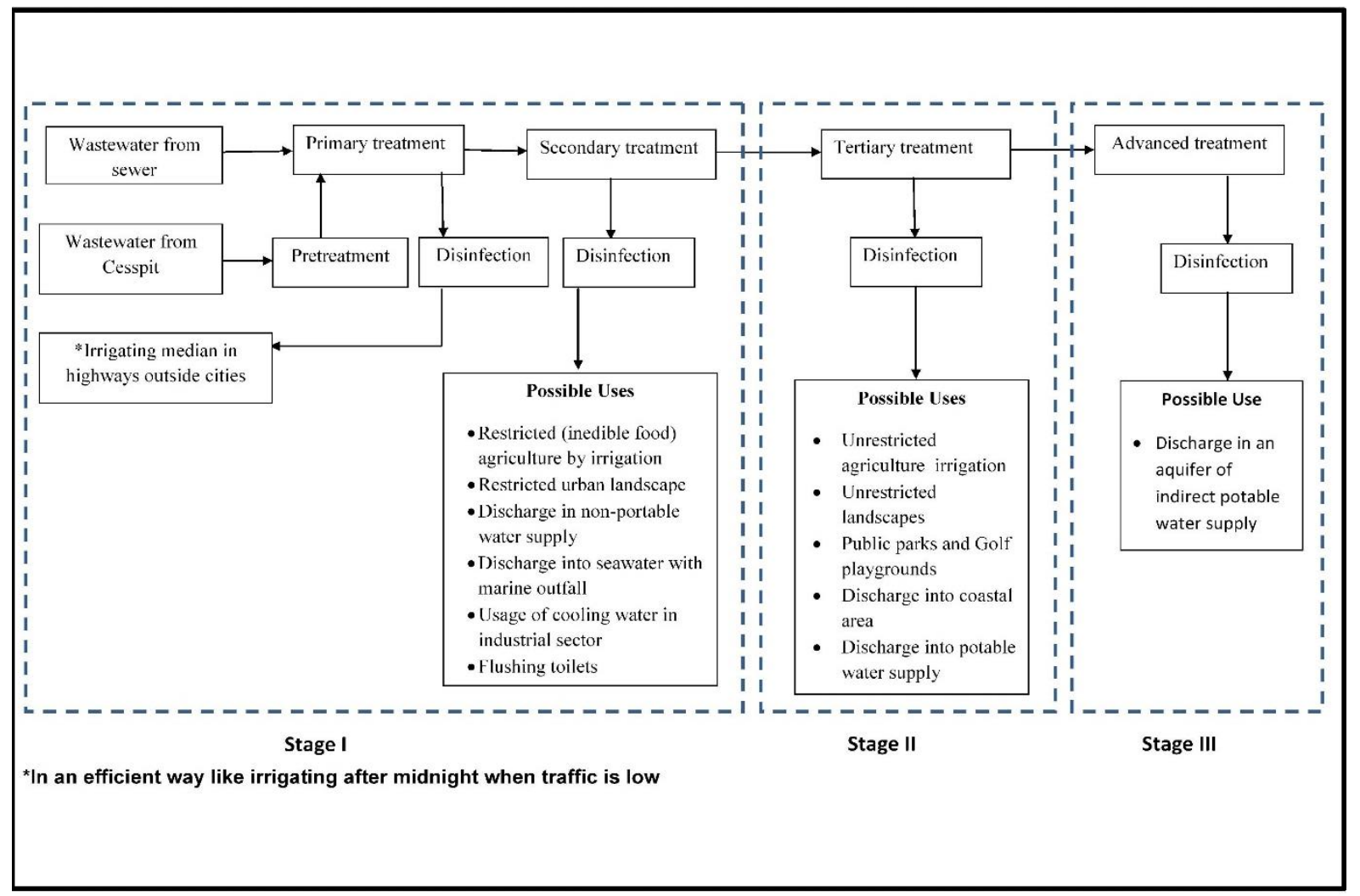

Figure 4. Flow diagram shows three stages of wastewater treatment and its possible and public uses

\subsection{Secondary}

1. Every effort should be made to make use of every drop of treated wastewater. It should be remembered that KSA is an arid land where water is precious.

2. The sewerage systems should be completed as soon as possible and high priority should be given to it because the absence of sewerage system has several negative consequences. Pollution cannot be well controlled and wastewater cannot be collected, treated and reused.

3. A further point is to use septic tanks rather than cesspits in rural areas for wastewater disposal. Their configurations and locations distance from any water supply groundwater storage should be identified and executed from the environmental and engineering point of view.

4. Until the study of the reuses/discharge locations is completed, the World Health Organization (WHO) guidelines for the degree of wastewater treatment may be followed (WHO, 2006).

\section{Acknowledgements}

I would like to acknowledge Dr. Zubair for his valuable comprehensive reading of the article and providing elaborate comments. I express my thanks to Prof Zubair for his suggestions. I would like to express my appreciation to Dr. Solaiman Ali for his linguistic editing.

A formal letter was sent to the following 8 individuals requesting them to provide some of the data required. They were kind enough to comply. I acknowledge and thank to each of them. Very special thanks are due to the following for their appreciable assistance in sending the data: 
1. Engineer Md. Ahmed Baghdadi, Vice-Minister, Ministry of Water and Electricity.

2. Mahfuz Hossain Al-Khadrawi, Director-General, of the Eastern Region, Ministry of Water and Electricity (MOWE).

3. Engineer Ibrahim Omran Al-Omran, General Manager, Operations and Maintenance, Environmental Engineering Dept. (Ministry of Water and Electricity), Dammam, Saudi Arabia.

4. Engineer Ibrahim Saleh Ar-Rugheba, Director-General of Wastewater Dept., Ministry of Water and Electricity, Qassim Region.

5. Engineer Abdullah Hasanain, Director-General, National Water Company, Makkah Region.

6. Engineer Obaid Al-Thaqafy, General Manager, Operations and Maintenance, National Water Company, Jeddah.

7. Engineer Abdurrahman Al-Jiffry, General Manager, Water and Wastewater Network, National Water Company.

8. Chemist Zahed Malaqa, Environmental Engineering Dept., NWC, Jeddah, Saudi Arabia.

\section{References}

Aburizaiza O.S., Hammer M.J., Farook S., El Rehaily A.M. (1994), Technical and economical evaluation of the wastewater treatment plants for improved performance in Saudi Arabia. Final report of KAAU-KACST project AR-11-079, King Abdulaziz University, Jeddah, Kingdom of Saudi Arabia.

Al-Jasser A.O. (2010), Saudi Wastewater reuse Standards for agriculture irrigation: Riyadh treatment plants effluent compliance, Journal of King Saud University-Engineering Sciences, 23, 1-8.

Asano T. and Levine A.D. (1996), Wastewater Reclamation Recycling and Reuse: Past Present and Future, Water Science and Technology, 33(10-11), 1-14.

Baum R., Luh J. and Bartram J. (2013), Sanitation: a global estimate of sewerage connections without treatment and the resulting impact on MDG progress, Environ. Sci. Technol., 47, 1994-2000, http://dx.doi.org/10.1021/es304284f. Available: http://www.insae-bj.org/statistiques.html

BOE (2000), Royal decree No. M/6 1421 H, corresponding to 2000 AD Bureau of Experts at the Council of Ministers, Riyadh, Saudi Arabia.

Duong K. and Saphores J-D.M. (2015), Obstacles to wastewater reuse: An overview, WIREs Water, 2(3), $199-214$. doi: 10.1002/wat2.1074.

EPA, (2012), Guidelines for Water Reuse. U.S. Environmental Protection Agency. U.S. Environmental Protection Agency Office of Wastewater Management Office of Water Washington, D.C. National Risk Management Research Laboratory Office of Research and Development Cincinnati, Ohio. U.S. Agency for International Development Washington, D.C.

FAO, (1992), Wastewater treatment and use in agriculture. Natural Resource Management and Environmental Department. Food and Agriculture Organization, United Nations. Prepared by Tyne and Wear, Environmental Control Engineering, University of Newcastle-upon-Tyne, Newcastle-upon-Tyne, UK.

Florke M. (2013), Personal communication, December 13.

Gatica J. and Cytryn E. (2013), Impact of treated wastewater irrigation on antibiotic resistance in the soil microbiome, Environ Sci Pollut Res Int., 20(6), 3529-3538. doi: 10.1007/s11356-013-1505-4.

Geng Y., Fu J., Sarkis J. and Xue B. (2011), Towards a national circular economy indicator system in China: an evaluation and critical analysis, J. Clean. Prod., 23, 216-224. http:// dx.doi.org/10.1016/j.jclepro.2011.07.005.

Hammer Mark, (1996), Water and wastewater technology third ed. ISBN 0-13-205626-7 Prentice hall, Englewood cliffs, New Jersey.

Hanjra M.A. and Qureshi M.E. (2010), Global water crisis and future food security in an era of climate change, Food Policy, 35(2), 1-15.

Hanjra M.A., Blackwell J., Carr G., Zhang F. and Jackson T.M. (2012), Wastewater irrigation and environmental health: Implications for water governance and public policy, International Journal of Hygiene and Environmental Health, 215, 255-269.

Hophmayer-Tokich S. and Krozer Yoram (2008), Public participation in rural area water management: experiences from the North Sea countries in Europe, Water International, 33(2), 243-257. 
Iyad A. Husain, (2010), Reuse of reclaimed waste water in Jordan: A comparison study of the international vis-à-vis Jordanian standards, Fourteenth International Water Technology Conference, IWTC 14, Cairo, Egypt.

Katsiardi P., Manoli E., Karavitis C. and Assimacopoulos D. (2005), Scenario Based Strategy Development for Integrated Water Management, Global Nest Journal, 7(3), 360-368.

Mahar G.A., Alamri N. and Aburizaiza O.S. (2014), Spatio-Temporal change assessment using normalize difference vegetative index and spectral analysis techniques for vegetation cover on Wadi Auranah, Global NEST Journal, 16(5), 955-965.

Marcus F. (1998) Water Recycling and Reuse: The environmental benefits. Water Division, region 9, EPA 909-F-98001, United States, and Environmental Protection Agency.

Metcalf and Eddy, Inc. (1991), Wastewater Engineering-Treatment, Disposal, and Reuse. $3^{\text {rd }}$ ed. McGraw-Hill Publishing Company, New York, New York. (DCN 00213)

Mike Wehner, (2010), Orange County's Groundwater Replenishment System - Potable Reuse for the Best Available Orange County Water District, Tampa, Florida.

Missimer T.M., Maliva R.G., Ghaffour N., Leiknes T. and Amy G.L. (2014), Managed Aquifer Recharge (MAR) Economics for Wastewater Reuse in Low Population Wadi Communities, Kingdom of Saudi Arabia, Water Journal, 6, 2322-2338. doi:10.3390/w6082322.

MOWE, (2011), Annual Report of Ministry of Water and Electricity, Ministry of Water and Electricity, Riyadh, Saudi Arabia.

MOWE, (2013), Annual Report of Ministry of Water and Electricity, Ministry of Water and Electricity, Riyadh, Saudi Arabia

Rao D.G., Senthilkumar R., Byrne A.J. and Feroz S. (2013), Wastewater Treatment: Advanced Processes and Technologies. CRC PRESS, Taylor and Francis, UK.

Richard Helmer \& Evanildo Hespanhol, (1997), Wastewater as a Resource, In: Water Pollution Control - A Guide to the Use of Water Quality Management Principles. The United Nations Environment Programme, the Water Supply \& Sanitation Collaborative Council and the World Health Organization.

Sato T., Qadir M., Yamamoto S., Endo T. and Zahoor A. (2013), Global, regional, and country level need for data on wastewater generation, treatment, and use, Agriculture Water Management, 130, 1-13.

Scheierling S.M. (2010), Improving Wastewater Use in Agriculture: An Emerging Priority, Policy Research Work Paper 5412. Washington, DC: World Bank.

United Nations Environment Program (UNEP), Environment for Development, (2010), Time to cure global tide of sick water. Retrieved from: http://www.unep.org/documents.multilingual/default.asp?DocumentID=617\&ArticleID=6504\&I=en\&t=long

United State Environmental Protection Agency. Water Division Region IX - EPA 909-F-98-001. Web site: http://www3.epa.gov/region9/water/recycling/.

United States Environmental Protection Agency (EPA), (2012), Dissolved Oxygen and Biochemical Oxygen Demand, Water Monitoring \& Assessment. Web site: http://water.epa.gov/type/rsl/ monitoring/vms52.cfm.

United States Environmental Protection Agency (US EPA), (2004), Primer for Municipal Wastewater Treatment (Report Number EPA 832-R-04-001). Retrieved from EPA 832-R-04-001. Office of Wastewater Management.

US EPA, (2012), Guidelines for Water reuse. EPA/R-12//618, CDM Smith 50 Hemisphere Street, Cambridge, MA 02139. USAID, Ronald Regan Building, 1300 Pennsylvania avenue N.W. Washington D.C. website: http://nepis.epa.gov/Adobe/PDF/P100FS7K.pdf .

US EPA, (2015), Water Program. United State Environmental Protection Agency. Web site: http://www3.epa.gov/region9/water/.US EPA, 2015. Water Recycling and Reuse: The Environmental Benefits.

Wang L.K. (2010), Coverage of the principles of air flotation technology and the fundamentals of water and wastewater flotation and lake restoration. In: Flotation Technology, Springer Science \& Business Media, USA.

WHO (2006), Guidelines for Safe reuse of wastewater, excreta and grey water. In: wastewater use in agriculture. Website: http://www.who.int/water_sanitation_health/wastewater/wwuvol2intro .pdf.

Wu L. (2009), Safe Application of Reclaimed Water Reuse in the Southwestern United States, University of California Division of Agriculture and Natural resources (ANR), publication 8357, USA. 